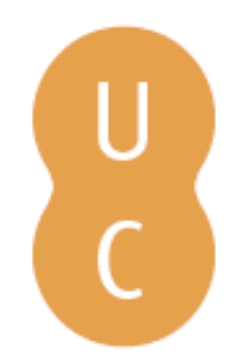

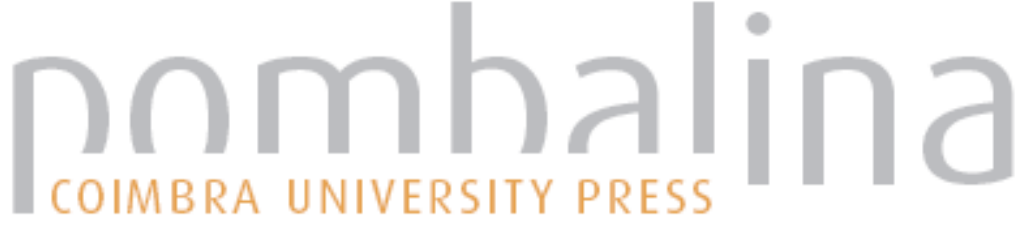

Calculating the population of a Roman provincial town: (Conimbriga, Prov. Lusitania, Portugal)
Autor(es):
Correia, Virgílio Hipólito
Publicado por: Imprensa da Universidade de Coimbra
URL
persistente:
URI:http://hdl.handle.net/10316.2/44753
DOI:
DOI:https://doi.org/10.14195/978-989-26-1566-0_2
Accessed : $\quad$ 26-Apr-2023 12:09:04

A navegação consulta e descarregamento dos títulos inseridos nas Bibliotecas Digitais UC Digitalis, UC Pombalina e UC Impactum, pressupõem a aceitação plena e sem reservas dos Termos e Condições de Uso destas Bibliotecas Digitais, disponíveis em https://digitalis.uc.pt/pt-pt/termos.

Conforme exposto nos referidos Termos e Condições de Uso, o descarregamento de títulos de acesso restrito requer uma licença válida de autorização devendo o utilizador aceder ao(s) documento(s) a partir de um endereço de IP da instituição detentora da supramencionada licença.

Ao utilizador é apenas permitido o descarregamento para uso pessoal, pelo que o emprego do(s) título(s) descarregado(s) para outro fim, designadamente comercial, carece de autorização do respetivo autor ou editor da obra.

Na medida em que todas as obras da UC Digitalis se encontram protegidas pelo Código do Direito de Autor e Direitos Conexos e demais legislação aplicável, toda a cópia, parcial ou total, deste documento, nos casos em que é legalmente admitida, deverá conter ou fazer-se acompanhar por este aviso.

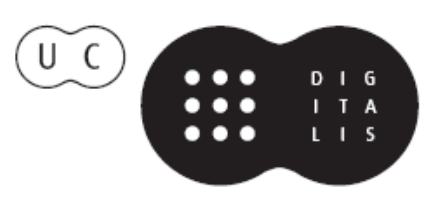




\section{História Antiga: Relações Interdisciplinares. Paisagens Urbanas, Rurais \& Sociais}

Carmen Soares, José Luís Brandão \& Pedro C. Carvalho (coords.) 


\title{
Calculating the population of a Roman provincial town (Conimbriga, prov. Lusitania, Portugal) ${ }^{1}$
}

\author{
Virgílio Hipólito Correia (vrglcorreia@gmail.com) \\ Museu Monográfico de Conímbriga \\ Centro de Estudos Clássicos e Humanísticos da Universidade de Coimbra
}

Abstract - Conimbriga (prov. Lusitania, current municipality of Condeixa-a-Nova, District of Coimbra, Portugal) is a Roman city of indigenous roots known since the sixteenth century, the subject of excavations and various publications since 1890 and, since 1930, the place of systematic archaeological excavations that have exposed the site and saved it as a major Roman site in the Iberian Peninsula.

A method for calculating the population number of a Roman town is presented, based on the study of the domestic architecture of the c. $20 \%$ of excavated area. The method allows to go beyond the mere number of inhabitants and to suggest some reconstruction of the structure of the population. Conclusion point to a small town (c. 5500 inhabitants) and a deeply stratified structure, with almost a third of slaves and dependents and a small decurionate class, not exceeding c. 7\% (around 40 families).

KEYwords - Roman population; municipal elites; domestic architecture

\section{INTRODUCTION}

Among various research projects on Conimbriga, a recent one can be mentioned, which dealt with the systematic study of the domestic architecture of the town, which although often referenced, particularly because of the preserved mosaics, had never been the subject of systematic treatment.

This situation is paradoxical. The archeological research in Conimbriga began with the domestic architecture. This is a feature that Conimbriga shares with towns such as Pompeii, Herculaneum and Ostia, but not with many other archaeological sites in the orb of the Roman empire.

The first four moments of city research, namely, the small excavations triggered by an occasional finding, in 1873, the first major excavations of 1899 , the excavation of the site by the Faculty of Letters in 1930 and the excavations from 1929 to 1944 by the DGEMN, exposed, all of them - temporarily the first two, definitely the others - domestic architectural fragments, and none of them, public monuments of significance ${ }^{2}$. The Late Empire city-wall, a public monument of substance, has never been subject to thorough research,

${ }^{1}$ Trabalho desenvolvido no âmbito do projeto UID/ELT/00196/2013, financiado pela FCT - Fundação para a Ciência e a Tecnologia.

${ }^{2}$ About the excavations of 1873, Gonçalves 1903: 359-365; For all other excavations. DGEMN 1948: 5-29 and Correia 1941: 257-267. 
its chronological interpretation was always based on the mistaken idea of its identification with the true edge of the city and the restoration itself that was developed without an archaeological investigation worthy of the name ${ }^{3}$.

In fact, down to the French-Portuguese excavations that started in 1964, the domestic architecture was all that was known of Conimbriga. It is therefore somewhat paradoxical as from that moment on, this domestic architecture was relegated to a secondary role in the investigation of the town.

After the French-Portuguese excavations, archaeological excavations in Conimbriga stagnated. In the late seventies and throughout the eighties of the XX century, some work in the street called "of the patera Emanuel" was carried out and, due needs of conservation, interventions in the House of the fountains and at the House of Cantaber ${ }^{5}$ as well as late-medieval graves were excavated in the palaeochristian basilica, but none of these interventions was integrated in a true research project and has never been the subject of systematic publication.

\section{Problems of Chronology}

The history of the research of domestic architecture of Conimbriga strongly determines the context in which this can be studied, this being mainly due to a factor: the extent and detail of our knowledge of the chronology of each of the buildings ${ }^{6}$.

The date of construction of a building is not the main thing to observe, but because the timescale of urban development and genetic links between the elements that compose it, in what the domestic architecture (or any other architecture) is concerned, are essential elements in the understanding of the social and demographic development underlying urban dynamics. The overview of this topic in Conimbriga is not particularly encouraging.

Until 1944, the archaeological excavations carried out in Conimbriga had no stratigraphic concern. As a rule, the excavation was limited to the exposure of the Roman buildings to the height of their pavements (determined by previous surveys). The rigor of the collection of materials is unknown, but appears to have been limited to a few relevant items and to have systematically neglected the collection of small ceramic fragments, and the reference of those collected items does not mention the house or building of origin (to ask for a minimum information), but only the fact that it comes from Conimbriga.

From 1953, excavations began to be carried using a system for collecting materials and maintaining their context references, as to associate them with the compartment of buildings where they were retrieved. However, a stratigraphic

\footnotetext{
${ }^{3}$ DGEMN 1948: 31 (V) and references on pp. 7-9.

${ }^{4}$ Alarcão \& Etienne 1977: 65-84, 135-142, 155-164.

${ }^{5}$ Correia 2001: 83-140.

${ }^{6}$ On this issue Correia \& Alarcão 2008; Correia 2013: 23-31.
} 
record system did not exist, whereby the difficulty in handling of the chronological data is still very significant for these contexts.

Only after 1962 were modern methods of excavation and recording adopted and, since 1964 a reliable data archiving system was created. This last element came to deteriorate in the practice of archaeological excavations after the closure of the French-Portuguese campaigns in 1971, and the less reliable system that is currently used, but the closer memory of the perpetrators of these recent excavations has somehow supplied this deficiency.

The consequence of this is that the chronological information on the domestic constructions of Conimbriga is characterized by vagueness.

The insulae in the central area area of the town seem to have been built in the Claudian period ${ }^{7}$. Other buildings identified in the area of French-Portuguese excavations have a timeline proposed by deductions from the urban development processes and the general presence of major datable classes of material.

The various proposed dates for the construction of the buildings seem to break off at the end of the I c. AD and the beginning of the II c. In the House of Cantaber, phase II, the one when the great house is built, was attributed to the Flavian period ${ }^{8}$. A major refurbishment of the House of the fountains, fruit of the same architectural line of invention, seems to have occurred in the reign of Hadrian'. On the latter date, everything else that is known in Conimbriga in the field of domestic architecture appears to be limited to only minor interventions or decorative work.

The first half of the II c. AD hence seems a good chorological framework within which our calculation of the population of the town can be carried out, representing the maximum extent of the occupied urban nucleus.

\section{Problems of conservation and documentation}

The research history also dictates the conditions in which we work, with regard to the conservation of buildings and their documentation.

From a historical perspective, it must first be mentioned the oldest global representation of the archaeological knowledge about Conimbriga, the map representing the surveys carried out under the direction of António Augusto Gonçalves, drawn to a scale 3.5 / 1000.

Later, in 1939, the Ministry of Public Works had a topographic plan of Conimbriga and its surroundings drawn, on which a designed extension of the access road was projected; this was the main access to the site until the nineties, and this plan was the basis for all publications and studies on Conimbriga for fifty years. With this general plan coexisted another survey of detail of the

\footnotetext{
${ }^{7}$ Alarcão \& Etienne 1977: 190-195.

${ }^{8}$ Correia 2001: 123-124.

${ }^{9}$ Correia 2004a: 54-55.
} 
excavated structures, made to scale $1 / 50$, the use of which also extended to the present day.

In 1964, with the start of French-Portuguese excavations, first under the direction of Robert Etienne and JM Bairrão Oleiro, began a phase of work that would more than double the excavated area and increase immeasurably our knowledge of the city, extending the project under the direction of the Portuguese part by Jorge Alarcão. The basic topography, however, remained the same. Over the same plans, the Mission Archéologique Française au Portugal and the Bureau d'Architecture Antique Pau deployed rigorous stone-by-stone surveys to the scale $1 / 50^{10}$ which covers the excavated the area, the monumental center; the overlaying of distinct plans was also made with considerable accuracy. However the rest of the city was not object of specific topography. The end result of this sum of representations was published in plan LII of the Fouilles de Conimbriga first volume, dedicated to architecture ${ }^{11}$.

In 2005 a digital document was finally produced, integrating all topographic data known about Conimbriga, properly referenced to its nature (land conformation, excavated structure, reconstituted structure, etc.) and its date ${ }^{12}$.For the topographical studies published in 2008 an ortophotogametric plan was taken as basis: over it all plans of the buildings of Conimbriga were placed, that had been scanned in 1998/9 as mentioned elsewhere ${ }^{13}$; in the case of thermal buildings, corrected plans published in a specific paper were used ${ }^{14}$.

The accuracy of this documentation is dependent of the preservation conditions of the building. From a strict perspective of conservation interventions, the residences of the east side of the city, excavated between 1929 and 1944 were all subject to a successive process of excavation and restoration without accurate documentation of the remains preserved and restored extension. Some photos allow a general assessment of the extent and depth of the restoration, but that is always a generic assessment, not a detailed one, and in fact there are important points of the buildings in which the interpretation of the original situation and the identification of the restored part is difficult. Even in areas where the extension of the restoration is obvious, the protection technique using the construction of two to three stone layers on the preserved original has been systematically employed, which does not allow for the reading of the manner of the construction of the original wall. The simple topographic plan is therefore the more accurate instrument that can be reliably used.

${ }^{10}$ Alarcão and Etienne 1977: vol. II, III pl.s, XIX, XX and, especially for the subject matter here, XXXIX.

\footnotetext{
${ }^{11}$ Alarcão \& Etienne 1977: loc. cit.

${ }^{12}$ Correia \& Alarcão 2008: 31-46.

${ }^{13}$ Ibidem.

${ }^{14}$ Reis \& Correia 2006: 293-312.
} 
The only exception to this is the insula of the aqueduct that has not undergone any significant restoration work.

In the area of the French-Portuguese excavations a stone-by-stone plan was drawn at the scale 1/50 and published the 1/100 scale for all structures; this is an instrument of superior documentary and analytical value. The conservation practice followed, which has been marked by a limited depth and extent of intervention, allows for autopsy in almost all buildings.

Subsequent interventions were and have been, in general, documented by drawing stone-to-stone to scale $1 / 20$, depending on the conservation status of the structures and the existence of previous documentation.

An overall assessment of the available documentation demonstrates that, in the present conditions, a consistent analysis of the excavated area can be made, although the in-depth analysis of individual buildings cannot be carried out to the same degree of accuracy. This is a main feature of all subsequent analyses of the archaeology of the town in its various aspects.

\section{THE RESEARCH ON THE DOMESTIC ARCHITECTURE IN THE TOWN}

In 2010 the systematic study of domestic architecture of the town was concluded, which analyzed in depth, the twenty-seven residential buildings, known in whole or in part ${ }^{15}$.

The nature of exposed areas in the excavated area of Conimbriga, with regard to its occupation, can be summarized as follows, which helps to put the domestic architecture in its position of relative importance:

\begin{tabular}{|l|c|c|}
\hline & $\mathbf{m}^{2}$ & $\%$ \\
\hline Total excavated area & 30216 & 100 \\
\hline Public buildings & 10283 & 34 \\
\hline Private buildings & 13948 & 46 \\
\hline Open space & 5985 & 20 \\
\hline
\end{tabular}

Table 1. Proportion of urban functions in the excavated area of Conimbriga.

The excavated area represents $13.6 \%$ of the total 22.2 hect. (all measurements were made on the digital plan of Conimbriga, with the underlying the data previously published ${ }^{16}$, using the tools provided by the software used). However, extrapolation of functional proportions observed for the whole city cannot be done directly.

First, it is unlikely that the remaining area, not excavated, of the city was so markedly occupied by public monuments. In the excavated area, the forum and

\footnotetext{
${ }^{15}$ Correia 2013: 53-173.

${ }^{16}$ Correia \& Alarcão 2008: 31-46.
} 
the three public baths (total $10283 \mathrm{~m} 2$ ) represent 34\%: this percentage clearly cannot be extrapolated. In Conimbriga, we know of, or we can reconstruct, the existence of an amphitheater ${ }^{17}$, a theater ${ }^{18}$ and a municipal forum ${ }^{19}$ : its total area can be reconstituted approximately at $10000 \mathrm{~m} 2$, which is a minimum value for the extent of public buildings in the city's total (9.1\%). Allowing for the existence of other monuments still unidentified, that could equate, all considered, the forum area $(4490 \mathrm{~m} 2)$ as a maximum, one would reach a maximum of 24773 $\mathrm{m} 2$, i.e. $11.2 \%$ of the total area of the town, what seems empirically acceptable.

At this point, failing to enter an infinite regression of assumptions, it is necessary to abandon the consideration of semi-public nature buildings like the scholae $^{20}$, which formed part of the private buildings side calculations. Occupancy rates of these units (housing, but not really residential) will not influence significantly the calculations and, in any case, any permanent residence in these facilities is to be considered (vigilance, maintenance, etc.).

Secondly, the available free space is certainly much higher in the urban edges than in the center and extrapolation of observed $20 \%$ surely incur a significant error by default, although this percentage at the first reading may be taken as meaningful. It is indeed observable that there is, inside the town area along the Early-Imperial wall, a significant extension where buildings are not observable ${ }^{21}$.

Measured on the shortest sure line this area is about $60 \mathrm{~m}$ wide, which would, if extended to the entire perimeter of the wall amount to 60000 to $65000 \mathrm{~m} 2$, representing from 30.3 to $32.6 \%$ of the total area. To this, it still needs adding up the existing circulation space in the remaining built-up area (where one can extrapolate the proportion observed in the excavated area, reaching final totals of 104,432 to $109,432 \mathrm{~m} 2,47$ to $49.3 \%$ of the total area). One can conclude, therefore, that almost half of the city area bounded by the Early-Imperial wall was not actually occupied by buildings, a substantial part being urban reserve for the growth of a population, which did not occur, due to historical reasons that cannot be inquired here, and was never used for construction.

The extrapolation can be made as in the following table, leaving the cover margin of uncertainty for the field of domestic architecture, so as to estimate, in all subsequent analyzes, the residual maximum error of the calculations carried out.

\footnotetext{
${ }_{17}^{17}$ Correia 1995: 237-269.

${ }^{18}$ Alarcão 2009: II 242.

${ }^{19}$ Correia 2009: 397-406.

${ }^{20}$ Correia 2013: 327-333; Correia in print.

${ }^{21}$ Correia 2004b: 261-298; Reis 2003: passim.
} 


\begin{tabular}{|l|c|c|}
\hline & $\mathbf{m}^{\mathbf{2}}$ & $\%$ \\
\hline Total area & 222161 & 100 \\
\hline Public buildings & $20283-24773$ & $9,1-11,2$ \\
\hline Open space & $104432-109432$ & $47,0-49,3$ \\
\hline Private buildings & $87956-97446$ & $39,5-43,9$ \\
\hline
\end{tabular}

Table 2. Reconstructed proportion of urban functions in the area of the town.

For further calculation will be taken a probable average value of $92701 \mathrm{~m} 2$ of area occupied by domestic buildings ( $41.7 \%$ of total area) subject to a possible error of $4745 \mathrm{~m} 2(+/-0.6 \%)$.

\section{The OCCUPATION OF THE DOMESTIC SPACES OF CONIMBRIgA}

The occupation of domestic spaces in the town and the availability of space for the inhabitants, as essential for calculating the number of city inhabitants was logically dependent on two distinct realities: the traditional structures of family cohabitation and life expectancy.

The best evidence to make estimates of these elements is epigraphy, despite all the inherent theoretical difficulties. About the problem there are traditional views ${ }^{22}$ criticised from the point of view of the statistical technique of the demographics ${ }^{23}$, but, overall, the approaches have evolved ${ }^{24}$, but in particular the specific situation of Conimbriga makes it necessary to proceed with great caution, since the sample is small. In the corpus of Conimbriga, 35 funerary inscriptions were considered to be in a position to be used ${ }^{25}$.

Therefore this sample will be used mainly as reference to the credibility of the extrapolation of more generally analyzed data ${ }^{26}$. This contrast is nevertheless of great importance, because the same general studies show that there are significant orders of magnitude in the variability found in different samples.

Hence, one can start at the basis that twenty-five funerary inscriptions are known in Conimbriga, which give, generally speaking, information on the sex and age of the deceased and about his relationship with the surviving person responsible for the dedication of the monument (it can accepted that such a person is the individual which at the date of death of the deceased, plays, or shall play henceforth a central role in its family structure). The thirty-five inscriptions relate to 38 different individuals, which are therefore the local contrast sample.

${ }^{22}$ Etienne 1957: 418-425; Moretti 1959: 60-78.

${ }^{23}$ Hopkins 1967: 245-264.

${ }^{24}$ Duncan-Jones 1990 [ch. 6]; Frier 1992: 286-290; recent revisions of the problem in Hin 2007; Scheidel 2007a.

${ }^{25}$ Etienne et al. 1976: $\mathrm{n}^{\mathrm{o}} \mathrm{s} 26,27,31-34,36,37,39,44-47,50,52-54,56-68$ and 70-74.

${ }^{26}$ Burn 1953: 25-45; id. 1965: 253-257; Frier 1992: 286-290. 
This number is insufficient for detailed analysis, but an element juts out immediately: of the 38 individuals, $23(60 \%)$ of the deceased are children or grandchildren of the inscription dedicants.

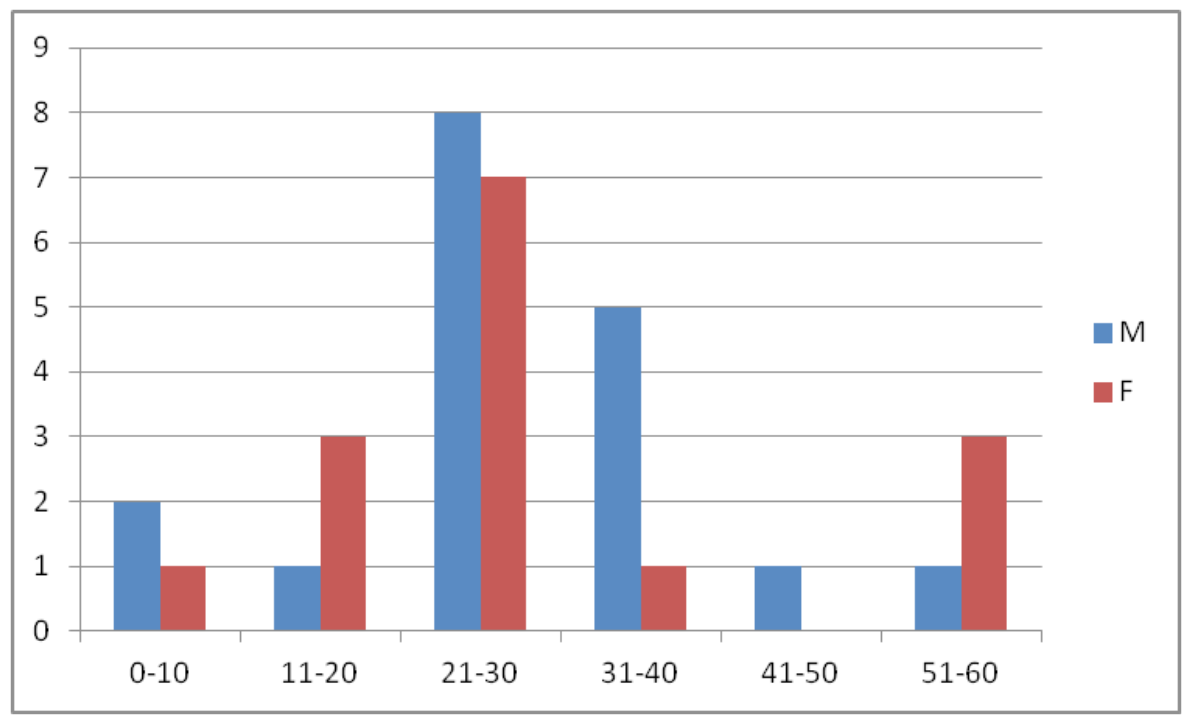

Table 3. Distribution, by sex, of the mortal age of the individuals recorded in inscriptions of Conimbriga.

So there is reason to think that a very significant percentage of individuals (sufficiently remarkable to be remembered with a tombstone) still lived depending on their parents at the time of their deaths, indicating a family model mainly multi-generational.

Another important element is that only 6 individuals (15\%) are identified as parent or patron of the dedicant, and their mean age at death is 44 years (the remaining 9 [25\%] are spouses, cognates or the kinship is unknown and there is a case sibi posuit).

An upper limit of life expectancy of around 40/50 years may, in the light of the overall evidence available, considered of a medium-high $\operatorname{order}^{27}$.

It is, however, possible to assess the problem of life expectancy but at the most elementary form: the distribution by sex, of the age of death observed among the 38 subjects, gives the results expressed in the graph above.

The interval with more occurrences of mortal age falls between 21 and 30 years, but with a significant difference in the behavior of the sexes. A substantial proportion of men die between 31 and 40 years, which does not happen with women, who on the contrary, often die before 20 , a fact prima facie attributable

\footnotetext{
${ }^{27}$ Scheidel 2001: 1-26.
} 
to perinatal maternal mortality ${ }^{28}$.

The peak of dedications to women aged 60 or more, must be attributed to likely sentimental reasons: those were the matriarchal figures, the "grannies", and should not be statistically valued as a demographic phenomenon, possibly in the same category of the over-representation of deaths of males before 10 years of age, inexplicable otherwise than special attention to memory in monuments of the lost presumptive heirs of families.

In short, the situation can be described as that of a very rapid succession of generations, in a pattern of multi-generational co-residence.

One can therefore offer the following picture for the reconstruction of family units:

\begin{tabular}{|l|c|c|}
\hline & Estimated minimum & Estimated maximum \\
\hline $\begin{array}{l}\text { Generation 1 } \\
\text { (ancestrals) }\end{array}$ & 1 & 2 \\
\hline $\begin{array}{l}\text { Generation 2 } \\
\text { (active adults) }\end{array}$ & 2 & 2 \\
\hline Generation 3 (children) & 1 & 3 \\
\hline $\begin{array}{l}\text { Dependents } \\
\text { (slaves or otherwise) }\end{array}$ & 1 & 4 \\
\hline Total of the family unit & 5 & 11 \\
\hline
\end{tabular}

Table 4. Reconstruction of possible households in Conimbriga.

The reconstruction of the number of servile dependents requires special justification ${ }^{29}$ : the lower limit is dictated by the assumption that most Romans actually owned a slave; reasons leading to not extend this to Conimbriga are not clear. The upper limit is based on the reasoning that the families of a certain size would normally require a number of servants that would ensure four basic functions: house surveillance, hygiene and cleaning, personal service of the paterfamilias and communication with the outside; the situations were, undoubtedly, very varied and truly fluid (one has only to think, for example, in the situation of rural slaves, whose stay in the city is seasonal, but within that seasonality, it is a regular fact). There are, however, good reasons to continue our reconstructions within these margins of uncertainty.

This reconstruction of maximum and minimum expected members of a family unit is the essential element of the calculation of the population of Conimbriga in the light of our knowledge of the urban structure and the morphology of domestic architecture. However this needs to be supported by

\footnotetext{
${ }^{28}$ Cf. Hopkins 1965: 309-327, but afterwards questioned id. 1967: 245-264.

${ }^{29} \mathrm{Cf}$. the recent line of research in support of this Scheidel 2005a, 2005b, 2007a.
} 
some additional assumptions, whose expression is vital for assessing the credibility of the final result.

In the first place, it should be postulated that in a scenario of abundant urban space, there was a close fit between the size of the family unit and the size of its residential unit; this have come to happen due to successive building adaptations to the eventualities of quantitative developments families or pure and simple relocation of the latter in new homes. It seems appropriate, therefore, to match a dispersion of estimated dimensions of family sizes to the distribution of residential units by groups determined by the area and number of cells of these units.

Secondly, the morphological analysis of buildings advises to leave out of this exercise, at this preliminary point of reasoning, both ends of the spectrum of residential unit groups, i.e. tabernae and major domus, because surely the space/ family ratio was in such extremes different from that existing at the center of the normal distribution. This point should be extended to three buildings of Group D: the insula of the aqueduct, whose internal structure and occupancy rate can only be restored from external examples, so it would be tautological its introduction in the calculation at this time; and the houses of skeletons and swastika, whose morphology advises to use them with the estimation method of floor area per inhabitant to be used in further points of this calculation.

Correspondence of the distributions of the expected size of family units with the observable residential unit size dispersion can be presented as follows:

\begin{tabular}{|l|c|c|c|c|c|}
\hline & $\begin{array}{c}\text { No of } \\
\text { considered } \\
\text { residential } \\
\text { units }\end{array}$ & $\begin{array}{c}\text { Mean area } \\
\text { of units }\end{array}$ & $\begin{array}{c}\text { Typical } \\
\mathbf{n}^{\mathbf{o}} \text { of cells } \\
\text { in unit }\end{array}$ & $\begin{array}{c}\text { Expected } \\
\text { dimension } \\
\text { of family }\end{array}$ & $\begin{array}{c}\text { Area per } \\
\text { inhabitant } \\
(\mathbf{m} 2)\end{array}$ \\
\hline Group B & 13 & 39,6 & 2 & $6(+/-1)$ & $\begin{array}{c}6,6 \\
(5,6-7,9)\end{array}$ \\
\hline Group C & 15 & 57,7 & 3 & $8(+/-1)$ & $\begin{array}{c}7,2 \\
(6,4-8,2)\end{array}$ \\
\hline Group D & 9 & 267 & 7 & $10(+/-1)$ & $\begin{array}{c}26,7 \\
(24,3-29,6)\end{array}$ \\
\hline
\end{tabular}

Table 5. Reconstruction of the occupation of median residential units in Conimbriga.

The first point to make about these numbers is that the availability of usable space per inhabitant of the residential unit appears to be an exponential function of the unit's position in the dispersion: the higher the unit, the larger, exponentially, is the area available for its inhabitants. The sociological interpretation of this mathematically observed fact is consistent with the empirical observations about the appropriation of space by the owners of homes, namely aristocratic 
ones, so it is possible to extrapolate these data to the ends of the spectrum.

However, the mere statistical progression logically faces a lower logistical limit: the minimum useful size of the unit. The upper limit, on the contrary, is one of enormous material variability; the size of households grow at the expense of servile dependents without specific allocated space, who are more numerous than the family members with rights of occupation of the domestic space: the extrapolation must necessarily be done by a method not quite orthodox.

The extrapolation of the number of inhabitants of the residential units in group $\mathrm{A}$ is of an arbitrary nature, based on the considerations made elsewhere about the nature and function of tabernae as urban settings.

The method of extrapolation used for larger homes, also due to the reduced number of classes, was carried in the following manner: the mean rate of growth of the area of the units was determined and, where possible the differential growth indices of available space per inhabitant. The linear correlation between these two indices was defined by the expression $\mathrm{y}=0,812 \mathrm{x}-0.037$, which allowed to extrapolate useful areas per inhabitant at the upper end of group D and group $\mathrm{E}$. This extrapolation indicates a number of inhabitants of large residence that although prima facie high, is not entirely far-fetched. The maximum and minimum limits were calculated by the same process, with satisfactory results, with the exception of the ceiling inhabitants of the residential units in Group E, which was corrected by an ad hoc process.

\begin{tabular}{|l|c|c|c|c|c|}
\hline & $\begin{array}{c}\text { No of } \\
\text { considered } \\
\text { residential } \\
\text { units }\end{array}$ & $\begin{array}{c}\text { Mean area } \\
\text { of units }\end{array}$ & $\begin{array}{c}\text { Typical no } \\
\text { of cells in } \\
\text { unit }\end{array}$ & $\begin{array}{c}\text { Expected } \\
\text { dimension } \\
\text { of family }\end{array}$ & $\begin{array}{c}\text { Area per } \\
\text { inhabitant } \\
(\mathrm{m} 2)\end{array}$ \\
\hline Group A & 35 & 27,2 & 1 & $2(+/-1)$ & $\begin{array}{c}13,6 \\
(9-27,7) \mathrm{a})\end{array}$ \\
\hline Group B & 13 & 39,6 & 2 & $6(+/-1)$ & $\begin{array}{c}6,6 \\
(5,6-7,9)\end{array}$ \\
\hline Group C & 15 & 57,7 & 3 & $8(+/-1)$ & $\begin{array}{c}7,2 \\
(6,4-8,2)\end{array}$ \\
\hline Group D & 9 & 267 & 7 & $10(+/-1)$ & $\begin{array}{c}26,7 \\
(24,3-29,6)\end{array}$ \\
\hline Group D* & 2 & 708 & $\begin{array}{c}11 \\
\text { (average) }\end{array}$ & $22(+/-8)$ & $\begin{array}{c}32,5 \\
(21-44) \mathrm{b})\end{array}$ \\
\hline Group E & 2 & 3075 & $\begin{array}{c}40 \\
\text { (avprage) }\end{array}$ & $74(+/-29)$ & $\begin{array}{c}41,7 \\
(29,8-68) \mathrm{b})\end{array}$ \\
\hline
\end{tabular}

Table 6. Reconstruction of global occupation of the residential units in Conimbriga 
An apparent problem, the large margin of error calculation of the inhabitants in big homes, actually is not: due to its large size but small number, their overall quantitative representation in the total sample is very limited, and as the ultimate objective of the statistical test is a global quantitative calculation, the representativeness of this variation will be much less important than it would for example, if possible variations in the most significant representative classes were to occur.

Under these conditions it is possible to present the first base of the calculation of the inhabitants of Conimbriga, namely, the estimated number of inhabitants in the excavated area.

\section{The Calculation of THE POPUlation OF Conimbriga}

The basis of calculation consists of the 75 cataloged residential units in the excavated area $^{30}$. The main problem of this survey is that it does not consider the existence of residential units in the upper floors of buildings.

Another problem has to do with the actual calculation method of the number of inhabitants: the traditional method in classical archeology involves the number of housing units and multiplying by the estimated number of people in the corresponding family unit; on the other hand, the prehistoric archeology usually deals with the population estimates through space available per capita (often taking a village as a whole).

In fact, most of the numerous literature on the calculation of the population of Rome ${ }^{31}$ used to its estimates a simple product residential units/number of individuals in the family unit. This method has the virtue of simplicity but lacks subtlety, and does not allow for variability in occupancy rates. For criticism of the method, it is useful to look outside the narrow confines of classical archeo$\log y^{32}$.

It seemed adequate for the situation of Conimbriga the iterative use of a mixed method. First, as was mentioned before, a regular distribution distribution of the estimated size of households along the group-type of residential units, including the extrapolation of data available for groups at the extremes of the series.

\footnotetext{
${ }^{30}$ Buildings not taken in consideration are Correia 2013 nos 1, 2, 5, 9 and 10, which have no bearing on the occupation ratio because they have not been excavated in any length; $\mathrm{n}^{\circ} \mathrm{s} 3$ (83m2 excavated), 4 (aprox. $120 \mathrm{~m} 2$ excavated), 8 (174,79m 2 excavated), 11 (aprox. 190m 2 excavated), 20 (286,18m2 excavated) and two independent areas of buildings, 14 - res. un. 5 $(28 \mathrm{~m} 2$ excavated) and 17 - res. un. 3 and $4(19 \mathrm{~m} 2$ excavated). Total area of domestic excavated buildings not attributable to completely cataloged residential units: $900,97 \mathrm{~m} 2$.

${ }^{31}$ From Beloch 1886; Hin 2007 and Scheidel 2007c to Calza 1917, Girri 1956, Packer 1967: 80-95; Brunt 1971 [2 $2^{\text {nd }}$ ed. 1987]; Cascio 1994; Storey 1997 and Frier 2000; to offer a diachronic overview without concern for thouroughness. For some instances in Lusitania Mantas 2013, 100-103.
}

${ }^{32}$ Cf. Kolb 1985: 581-599. 
Calculating the population of a Roman provincial town (Conimbriga, prov. Lusitania, Portugal)

\begin{tabular}{|c|c|c|c|c|c|c|c|c|c|c|c|c|}
\hline \multirow[b]{2}{*}{ Edifício } & \multirow[b]{2}{*}{ Unidade } & & & Cálc & lo $\mathrm{p} /$ unida & des & & & Cálc & ulo p/ áreas & & \\
\hline & & Área total & Grupo & Hab min & Hab med & Hab max & M2/hab min & M2/hab med & M2/hab max & № hab min & № hab med & № hab max \\
\hline 6 & 1 & 47 & C & 7 & 8 & 9 & 6,4 & 7,2 & 8,2 & 5,7 & 6,5 & 7,3 \\
\hline 6 & 2 & 510 & D & 9 & 10 & 11 & 24,3 & 26,7 & 29,6 & 17,2 & 19,1 & 21,0 \\
\hline 7 & 1 & 30 & B & 5 & 6 & 7 & 5,6 & 6,6 & 7,9 & 3,8 & 4,5 & 5,4 \\
\hline 7 & 2 & 300 & D & 9 & 10 & 11 & 24,3 & 26,7 & 29,6 & 10,1 & 11,2 & 12,3 \\
\hline 12 & 2 & 77 & C & 7 & 8 & 9 & 6,4 & 7,2 & 8,2 & 9,4 & 10,7 & 12,0 \\
\hline 12 & 1 & 128 & D & 9 & 10 & 11 & 24,3 & 26,7 & 29,6 & 4,3 & 4,8 & 5,3 \\
\hline 13 & 3 & 20 & A & 1 & 2 & 3 & 9 & 13,6 & 27,7 & 0,7 & 1,5 & 2,2 \\
\hline 13 & 4 & 20 & A & 1 & 2 & 3 & 9 & 13,6 & 27,7 & 0,7 & 1,5 & 2,2 \\
\hline 13 & 5 & 20 & A & 1 & 2 & 3 & 9 & 13,6 & 27,7 & 0,7 & 1,5 & 2,2 \\
\hline 13 & 6 & 20 & A & 1 & 2 & 3 & 9 & 13,6 & 27,7 & 0,7 & 1,5 & 2,2 \\
\hline 13 & 1 & 65 & C & 7 & 8 & 9 & 6,4 & 7,2 & 8,2 & 7,9 & 9,0 & 10,2 \\
\hline 13 & 2 & 293 & D & 9 & 10 & 11 & 24,3 & 26,7 & 29,6 & 9,9 & 11,0 & 12,1 \\
\hline 14 & 2 & 27 & A & 1 & 2 & 3 & 9 & 13,6 & 27,7 & 1,0 & 2,0 & 3,0 \\
\hline 14 & 4 & 38 & B & 5 & 6 & 7 & 5,6 & 6,6 & 7,9 & 4,8 & 5,8 & 6,8 \\
\hline 14 & 1 & 64 & C & 7 & 8 & 9 & 6,4 & 7,2 & 8,2 & 7,8 & 8,9 & 10,0 \\
\hline 14 & 3 & 46 & C & 7 & 8 & 9 & 6,4 & 7,2 & 8,2 & 5,6 & 6,4 & 7,2 \\
\hline 15 & 1 & 29 & A & 1 & 2 & 3 & 9 & 13,6 & 27,7 & 1,0 & 2,1 & 3,2 \\
\hline 15 & 3 & 22 & A & 1 & 2 & 3 & 9 & 13,6 & 27,7 & 0,8 & 1,6 & 2,4 \\
\hline 15 & 4 & 18 & A & 1 & 2 & 3 & 9 & 13,6 & 27,7 & 0,6 & 1,3 & 2,0 \\
\hline 15 & 5 & 17 & A & 1 & 2 & 3 & 9 & 13,6 & 27,7 & 0,6 & 1,3 & 1,9 \\
\hline 15 & 6 & 11 & A & 1 & 2 & 3 & 9 & 13,6 & 27,7 & 0,4 & 0,8 & 1,2 \\
\hline 15 & 12 & 29 & A & 1 & 2 & 3 & 9 & 13,6 & 27,7 & 1,0 & 2,1 & 3,2 \\
\hline 15 & 13 & 44 & A & 1 & 2 & 3 & 9 & 13,6 & 27,7 & 1,6 & 3,2 & 4,9 \\
\hline 15 & 8 & 34 & B & 5 & 6 & 7 & 5,6 & 6,6 & 7,9 & 4,3 & 5,2 & 6,1 \\
\hline 15 & 9 & 31 & B & 5 & 6 & 7 & 5,6 & 6,6 & 7,9 & 3,9 & 4,7 & 5,5 \\
\hline 15 & 10 & 37 & C & 7 & 8 & 9 & 6,4 & 7,2 & 8,2 & 4,5 & 5,1 & 5,8 \\
\hline 15 & 2 & 107 & D & 9 & 10 & 11 & 24,3 & 26,7 & 29,6 & 3,6 & 4,0 & 4,4 \\
\hline 15 & 7 & 101 & D & 9 & 10 & 11 & 24,3 & 26,7 & 29,6 & 3,4 & 3,8 & 4,2 \\
\hline 15 & 11 & 120 & D & 9 & 10 & 11 & 24,3 & 26,7 & 29,6 & 4,1 & 4,5 & 4,9 \\
\hline 16 & 1 & 20 & A & 1 & 2 & 3 & 9 & 13,6 & 27,7 & 0,7 & 1,5 & 2,2 \\
\hline 16 & 2 & 49 & A & 1 & 2 & 3 & 9 & 13,6 & 27,7 & 1,8 & 3,6 & 5,4 \\
\hline 16 & 3 & 23 & A & 1 & 2 & 3 & 9 & 13,6 & 27,7 & 0,8 & 1,7 & 2,6 \\
\hline 16 & 4 & 19 & A & 1 & 2 & 3 & 9 & 13,6 & 27,7 & 0,7 & 1,4 & 2,1 \\
\hline 16 & 5 & 25 & A & 1 & 2 & 3 & 9 & 13,6 & 27,7 & 0,9 & 1,8 & 2,8 \\
\hline 16 & 6 & 144 & D & 9 & 10 & 11 & 24,3 & 26,7 & 29,6 & 4,9 & 5,4 & 5,9 \\
\hline 17 & 1 & 25 & A & 1 & 2 & 3 & 9 & 13,6 & 27,7 & 0,9 & 1,8 & 2,8 \\
\hline 17 & 2 & 22 & A & 1 & 2 & 3 & 9 & 13,6 & 27,7 & 0,8 & 1,6 & 2,4 \\
\hline 18 & 1 & 53 & B & 5 & 6 & 7 & 5,6 & 6,6 & 7,9 & 6,7 & 8,0 & 9,5 \\
\hline 18 & 2 & 66 & C & 7 & 8 & 9 & 6,4 & 7,2 & 8,2 & 8,0 & 9,2 & 10,3 \\
\hline 19 & 1 & 48 & B & 5 & 6 & 7 & 5,6 & 6,6 & 7,9 & 6,1 & 7,3 & 8,6 \\
\hline 19 & 2 & 34 & B & 5 & 6 & 7 & 5,6 & 6,6 & 7,9 & 4,3 & 5,2 & 6,1 \\
\hline 19 & 3 & 40 & B & 5 & 6 & 7 & 5,6 & 6,6 & 7,9 & 5,1 & 6,1 & 7,1 \\
\hline 19 & 4 & 32 & B & 5 & 6 & 7 & 5,6 & 6,6 & 7,9 & 4,1 & 4,8 & 5,7 \\
\hline 19 & 5 & 37 & B & 5 & 6 & 7 & 5,6 & 6,6 & 7,9 & 4,7 & 5,6 & 6,6 \\
\hline 19 & 6 & 39 & B & 5 & 6 & 7 & 5,6 & 6,6 & 7,9 & 4,9 & 5,9 & 7,0 \\
\hline 21 & 1 & 40 & A & 1 & 2 & 3 & 9 & 13,6 & 27,7 & 1,4 & 2,9 & 4,4 \\
\hline 21 & 3 & 35 & A & 1 & 2 & 3 & 9 & 13,6 & 27,7 & 1,3 & 2,6 & 3,9 \\
\hline 21 & 5 & 64 & B & 5 & 6 & 7 & 5,6 & 6,6 & 7,9 & 8,1 & 9,7 & 11,4 \\
\hline 21 & 2 & 36 & C & 7 & 8 & 9 & 6,4 & 7,2 & 8,2 & 4,4 & 5,0 & 5,6 \\
\hline 21 & 4 & 83 & C & 7 & 8 & 9 & 6,4 & 7,2 & 8,2 & 10,1 & 11,5 & 13,0 \\
\hline 21 & 6 & 600 & D & 9 & 10 & 11 & 24,3 & 26,7 & 29,6 & 20,3 & 22,5 & 24,7 \\
\hline 22 & 1 & 3260 & $E$ & 45 & 74 & 103 & 29,8 & 41,7 & 68 & 47,9 & 78,2 & 109,4 \\
\hline 23 & 1 & 61 & A & 1 & 2 & 3 & 9 & 13,6 & 27,7 & 2,2 & 4,5 & 6,8 \\
\hline 23 & 2 & 61 & A & 1 & 2 & 3 & 9 & 13,6 & 27,7 & 2,2 & 4,5 & 6,8 \\
\hline 23 & 3 & 700 & D & 9 & 10 & 11 & 24,3 & 26,7 & 29,6 & 23,6 & 26,2 & 28,8 \\
\hline 24 & 2 & 26 & A & 1 & 2 & 3 & 9 & 13,6 & 27,7 & 0,9 & 1,9 & 2,9 \\
\hline 24 & 3 & 19 & A & 1 & 2 & 3 & 9 & 13,6 & 27,7 & 0,7 & 1,4 & 2,1 \\
\hline 24 & 4 & 17 & A & 1 & 2 & 3 & 9 & 13,6 & 27,7 & 0,6 & 1,3 & 1,9 \\
\hline 24 & 5 & 2 & A & 1 & 2 & 3 & 9 & 13,6 & 27,7 & 0,1 & 0,1 & 0,2 \\
\hline 24 & 1 & 2890 & E & 45 & 74 & 103 & 29,8 & 41,7 & 68 & 42,5 & 69,3 & 97,0 \\
\hline 25 & 1 & 44 & A & 1 & 2 & 3 & 9 & 13,6 & 27,7 & 1,6 & 3,2 & 4,9 \\
\hline 25 & 4 & 15 & A & 1 & 2 & 3 & 9 & 13,6 & 27,7 & 0,5 & 1,1 & 1,7 \\
\hline 25 & 5 & 32 & A & 1 & 2 & 3 & 9 & 13,6 & 27,7 & 1,2 & 2,4 & 3,6 \\
\hline 25 & 6 & 15 & A & 1 & 2 & 3 & 9 & 13,6 & 27,7 & 0,5 & 1,1 & 1,7 \\
\hline 25 & 9 & 44 & A & 1 & 2 & 3 & 9 & 13,6 & 27,7 & 1,6 & 3,2 & 4,9 \\
\hline 25 & 2 & 60 & C & 7 & 8 & 9 & 6,4 & 7,2 & 8,2 & 7,3 & 8,3 & 9,4 \\
\hline 25 & 3 & 80 & C & 7 & 8 & 9 & 6,4 & 7,2 & 8,2 & 9,8 & 11,1 & 12,5 \\
\hline 25 & 7 & 54 & C & 7 & 8 & 9 & 6,4 & 7,2 & 8,2 & 6,6 & 7,5 & 8,4 \\
\hline 25 & 8 & 48 & C & 7 & 8 & 9 & 6,4 & 7,2 & 8,2 & 5,9 & 6,7 & 7,5 \\
\hline 26 & 1 & 736 & D & 14 & 22 & 30 & 21 & 32,5 & 44 & 16,7 & 22,6 & 35,0 \\
\hline 27 & 5 & 26 & A & 1 & 2 & 3 & 9 & 13,6 & 27,7 & 0,9 & 1,9 & 2,9 \\
\hline 27 & 4 & 35 & B & 5 & 6 & 7 & 5,6 & 6,6 & 7,9 & 4,4 & 5,3 & 6,3 \\
\hline 27 & 2 & 65 & C & 7 & 8 & 9 & 6,4 & 7,2 & 8,2 & 7,9 & 9,0 & 10,2 \\
\hline 27 & 3 & 38 & C & 7 & 8 & 9 & 6,4 & 7,2 & 8,2 & 4,6 & 5,3 & 5,9 \\
\hline 27 & 1 & 680 & D & 14 & 22 & 30 & 21 & 32,5 & 44 & 15,5 & 20,9 & 32,4 \\
\hline Sub-totais & & 12847 & & 411 & 556 & 701 & & & & 427,3 & 567,8 & 724,3 \\
\hline Outros edif & cios & 901 & & & & & 6,4 & 7,2 & 8,2 & 109,9 & 125,1 & 140,8 \\
\hline Pisos supl & nentares & 2790 & & & & & 6,4 & 7,2 & 8,2 & 340,2 & 387,5 & 435,9 \\
\hline
\end{tabular}

Table 7. Reconstruction of the occupation of the residential units in Conimbriga. 
This process provides means and variances for the available space per capita, according to the group-type that each residential unit belongs. This allows, in a third and final step, to estimate the population volume of residential units and correct the results according to the empirical analysis of deviation factors (upper floors of buildings not represented in the sample). We present the results of the both methods as a control element.

It is noted that the method preferred here gives results 3 to $4 \%$ higher than simply counting the potential for people living in each unit. Laterally, it may be added that disagreements like this may have to do with some global fluctuations in population calculations ${ }^{33}$, but such oscillations can hardly be deemed to have the historiographical consequences suggested on occasions ${ }^{34}$.

The overall variation is not particularly significant, but it should be noted that it can, to some extent, correspond to a sociological reality: faced with a "normal" occupancy rate (reconstituted by the product method inhabitants/ units) one could possibly identify the existence of phenomena overcrowding with all the available space occupied at the logistical limit (best witnessed by the product method availability per capita/area units). In short, in further calculating and analyzing Conimbriga's population volume the mixed method will be used, while taking into account that, at the lower limit of this calculation there is an additional possibility of further lowering the limit (around 5\%), which will allow to better compare the local results with those of other cities of the Empire, where the simpler method was used to calculate the population.

There remains the problem of the correction factors of the calculation basis, which are the built area of domestic buildings not considered in its cataloging and the area of additional floors of some of the buildings. The first factor, has already been computed in $900,97 \mathrm{~m} 2$, an area that should not be extrapolated to the general city because it was already considered in the area of domestic excavated buildings; the second can be computed in $2790 \mathrm{~m} 2$, which are extrapolated to the global city in the calculation of its population, they constitute an inhabited built area, with a differential that is higher than the gross floor area of buildings by $20 \%$.

Upper floors considered were the two reconstituted upper floors of the insula of the aqueduct $(859 \mathrm{~m} 2$ each), the upper floors and basement of the building south of the road $(147.5 \mathrm{~m} 2 \mathrm{each})$ the lower floor of the north area of the house of the fountains $(600 \mathrm{~m} 2)$ and the area of the upper floor of the façade of the house of the swastika $(105 \mathrm{~m} 2)$. It seemed irrelevant to these calculations, the additional space of the residential units available for mezzanines, because they

${ }^{33}$ Such as the revisions of Brunt 1987: 113-120; and Cascio 1994: 23-40; on the original numbers of Beloch 1886: 370-378; respectively for larger and smaller numbers

${ }^{34}$ Scheidel 2004: 2-3: “if the 'high' count were correct, much of Roman history would have to be re-written". 
do not influence either directly or indirectly the number of housing units; its influence, which may have been significant, affects the available space per inhabitant, and is therefore part of the uncertainty of the limits inherent in any exercise of calculation.

Architectural considerations indicated that the majority of the residential units in these upper areas should have been integrated in group C-type dwellings, and the calculation was continued on that basis.

The calculation of inhabitants of the excavated fraction of Conimbriga, in the specific conditions of the method used and with the margin of uncertainty inherent in some of the archaeological realities involved offers three different values: 807 inhabitants as a minimum; 1080 as median and 1301 as maximum. This distribution is not symmetrical, as already referred, due to the need to consider lower values in the order of 3-4\% to ensure the comparability of these calculations with others made to other cities by the method of product inhabitants/units.

To sum it up, a median value of 1080 inhabitants (+/- 20\%) for the downtown area shall be deemed to be reasonably accurate. The asymmetry of the values is corrected in this manner, because the higher variability (+/- 221 inhab.) is almost completely equivalent to the lower variability (+/- 203 inhab.) if the increase of $4 \%$ given by the correction method is taken into account, with the difference being of reduced significance as to be neglected.

To extrapolate these numbers given from the excavated area for the calculation of the total population Conimbriga we must take into account the excavated area occupied by domestic constructions $(13948 \mathrm{~m} 2)$, the calculation of the inhabitants on the ground floor plan of these buildings (692, without the correction factor on the upper floors ), the minimum and maximum limits of the area occupied by domestic constructions in the city as a whole (which is calculated in $87956 \mathrm{~m} 2$ and $97446 \mathrm{~m} 2$ respectively) and a correction factor for the upper floors of buildings (+20\%). The margin of error inherent in the calculation is $20 \%$.

The result indicates that Conimbriga had between 5236 and 5801 inhabitants (not counting the deviation due to error) or, more accurately, $5575(+/-$ 25\%) inhabitants.

It was therefore a small (and spacious) town, endowed with an abundance of water, provided by an aqueduct that carried enough water to almost four times the population, and provided with an amphitheater that could accommodate more than three quarters of them ${ }^{35}$.

But beyond this phenomenological assessment (rosier than reality, no doubt), there are characteristics of such a community, which should be explored more in depth.

\footnotetext{
${ }^{35}$ For different calculations: Alarcão \& Etienne 1977, 60; Mantas 2013, 110-11.
} 


\section{An ASSESSMENT OF THE SOCIO-ECONOMic STRUCTURE OF Conimbriga}

The first significant approach to the social structure of Conimbriga that is important to pursue, among other reasons because of the importance that its numerical quantitative had in the estimate of the size of households, is the proportion of servile dependents (slaves or eventually freedmen in a position of strict functional dependency and cohabitation with the patron) in the general population.

The presence of one slave for each residential unit in groups $A$ and $B, 2$ slaves per unit in group $\mathrm{C}$ and 4 slaves in houses in group $\mathrm{D}$ was assumed in the calculation method for the general population (using the product units/inhabitants). It was also assumed that the units at the top of group D and group $\mathrm{E}$ households would comprise a maximum of 11 individuals ingenui and all other inhabitants would be servile dependents. The result is a total of 264 servile dependents in a group of 556 (mean) to 701 (max.) inhabitants. It should be considered that the minimum value for servile dependents in the population is to be discarded due to the specially large representation that should be assumed at the lower end of the distribution, which has to do with group A residential units: tabernae ${ }^{36}$. The overall conclusion is that between 37.6 and $47.5 \%$ of the population (as represented in the excavated area of the center of the town) was composed of servile dependents.

Having established the probable ratio between serviles and ingenui, the dichotomy at the base of the Roman social structure, there remains to be assessed the internal division of the free segment of the population. For this, it is essential to bridge the gap between the available evidence (the domestic architecture, in particular the volume of its construction) and its economic significance. This is an open, and partially untested, field of research: the deductions one can make are somewhat removed from the limited available data, and the fluid boundaries between a legitimate assumption and an ad hoc hypothesis is here especially dimmed. However, as has been repeatedly said, and in the case Conimbriga a special case in the Roman Empire, due to the nature and extent of preserved evidence, and if one acknowledges that we are here to work with orders of magnitude, more than with accurate statistics, the exercise is justified.

The exercise is based on a probable (albeit imprecise) estimate of the value of the residences based, on the one hand, on the estimates of the cost of public buildings of the town and, on the other, on estimates on relative volumes of construction of public and private constructions.

Using the rules of extrapolation that have been already used, it should be considered that the area of the two larger houses, whose value probably exceeded $100000 \mathrm{HS}$ plus half the total area of the houses whose value is less than that value, but higher than $33000 \mathrm{HS}$ (a third of the previous amount), amount to

\footnotetext{
${ }^{36}$ Cf. Scheidel 2005a, 64-67.
} 
$8073 \mathrm{~m} 2(57,9 \%$ of the excavated area). If this represents, as it is argued, the residences of those families which wealth surpassed the limit that Pliny the Young mentions as the census for the decurionate (with a third of it invested in the family residence as a sensible indicator), the city might have included between 35 and 38 houses in this upper group, corresponding to families comprising 385 and 418 individuals ingenui or, in other words, a fraction 7 or $7.5 \%$ of the population (all ages and both sexes confused) formed the upper stratum of society, from which was formed the ordo decurionum of Conimbriga, consisting of less than forty individuals (the patres familiae).

In short the social structure of Conimbriga appears threefold in this reconstruction: a servile stratum comprising between 37.6 and $47.5 \%$ of the population; a mass of free citizens of moderate economic expression - the "petits gents" mentioned in the Fouilles of Conimbriga, the "cetto medio" of Pompeii, the plebs media ${ }^{37}$ - representing between 45 and $55.4 \%$ of the population; and a small decurional elite, representing only 7 to $7.5 \%$ of the population, but who dominates directly almost over $50 \%$ of urban space; its effective control was undoubtedly even higher, thanks to the realities of patronage and leased property. It was therefore a most strongly stratified society.

From an urban point of view, there is also evidence that this stratification corresponded to a significant segregation of urban areas (undoubtedly mitigated by the simultaneous frequentation of public places), something that raises a third crucial element in the analysis of any society: vertical mobility.

There is no doubt that there was in the town a significant percentage of freedmen, which should be credited on a fluid mobility between the lower and the intermediate layers ${ }^{38}$. On the other hand, even if the reconstitution of the demographic volume of Conimbriga has given results significantly below notions traditionally managed, - synonymous with a not very large economic scale - indicates there were not excessively large enrichment possibilities for family units to pursue, hence, competition for social status must have produced significant tensions in society: the lower limits of the upper stratum of Conimbriga's society, which seem to have been truly on the very limits of the decurional census, and who were simultaneously subjected to great pressure for spending on social representation, surely witnessed and suffered significant movements degradation of socio-economic status.

But there is another reality that statistics cannot eliminate: the existence of a very short elite, that probably never exceeded a dozen families, about $3 \%$ of the population, which dominate the residences that, in Conimbriga, "have everything".

These families typically are not the most engaged in municipal life, at

${ }^{37}$ Veyne 2002: 1169-1199; Wallace-Hadrill 2008: 454.

${ }^{38}$ Scheidel 2005a: 76. 
least from the point of view of munificence ${ }^{39}$, which reinforces the perspective proposed elsewhere that the scope of social promotion is designed in other environments rather than their civitas natalis and, on the other hand, accentuates the more general perception that the competition for social status is more directly a product of status anxiety of the emerging classes, than the pursuit of a higher status by those who dominate ${ }^{40}$.

\section{BibliograPHY}

Alarcão, J. \& Etienne, R. (1977), Fouilles de Conimbriga I, L'architecture .Paris. Alarcão e Silva, P. D. S. (2009), Construir na Ruina. A propósito da cidade romanizada de Conimbriga. Porto.

Andreu Pintado, J. (2004), Munificencia publica en la Provincia Lusitania (siglos $I-I V$ d.C.). Zaragoza.

Beloch, K. J. (1886), Die Bevölkerung der griechish-römischen Welt. Leipzig.

Brunt, P. A., (1987, 2nd ed.) Italian manpower 225BC-AD14. Oxford.

Brunt, P. A. (1990), Roman imperial themes. Oxford.

Burn, A. R. (1953), "Hic breve vivitur: a study of the expectation of life in the Roman Empire", Past and Present 4: 25-45.

Burn, A. R. (1965), "Recensão de H. Nordberg (1963) Biometrical Notes", Journal of Roman Studies 55: 253-257.

Calza, G. (1917), "La statistica delle abitzioni e il calcolo della popolazione in Roma imperiale", Rendiconti della Reale Accademia dei Lincei, 5th s. 26: 60-87.

Cascio, E. (1994), "The size of the Roman population: Beloch and the meaning of the Augustan census figures". Journal of Roman Studies 84: 23-40.

Correia, V.(1941), "Las mas recientes excavaciones romanas de interes en Portugal. La ciudad de Conimbriga”. Archivo Español de Arqueologia 43: 257-267.

Correia, V. H. (1995), "The Iron Age in South and Central Portugal and the emergence of Urban Centres”, in B. Cunliffe e S. Keay (eds.) Social complexity and the development of towns in Iberia, from the Copper Age to the Second Century AD. Oxford, 237-262.

${ }^{39}$ Andreu 2004: 143-197; about Emerita specifically Saquete 1997: 161-170.

${ }^{40}$ Wallace-Hadrill 2008: 345-355. 
Correia, V. H. (2001), "Conimbriga. Casa atribuída a Cantaber. Trabalhos arqueológicos 1995-1998”, Conimbriga 40: 83-140.

Correia, V. H. (2004a), "O futuro dos estudos arqueológicos em Conimbriga", in V. H. Correia (ed.) Perspectivas sobre Conimbriga. Lisboa, 49-80.

Correia, V. H. (2004b), "Coexistência e revolução. Urbanismo e arquitectura em Conimbriga (séc. I a.C.-IIId.C.)”, in M. C. Lopes e R. Vilaça (coord.) $O$ passado em cena: narrativas e fragmentos. Miscelânea oferecida a Jorge de Alarcão. Coimbra, 261-298.

Correia, V. H. (2009), "Os espaços forais de Conimbriga", in P. Mateos, S. Celestino, A. Pizzo e T. Tortosa (eds.) Santuarios, oppida y ciudades: arquitectura sacra en el origen y desarrollo urbano del Mediterráneo Occidental. Madrid, 397-406.

Correia, V. H. (2013), A arquitectura doméstica de Conimbriga e as estruturas económicas e sociais da cidade romana. Coimbra.

Correia, V. H. (in print), "A identificação de scholae no tecido urbano de Conimbriga (prov. Lusitania, Portugal)", in O. Rodríguez Gutierrez (ed.), Los espacios de reunión de las asociaciones romanas. Diálogos desde la arqueologia y la historia. Sevilla.

Correia, V. H. \& Alarcão, P. (2008), "Conimbriga: um ensaio de topografia histórica”, Conimbriga 47: 31-46.

DGEMN - Direç̧ão Geral dos Edifícios e Monumentos Nacionais (1948), Ruinas de Conimbriga. Boletim Monumentos, no 52-53. Lisboa.

Duncan-Jones, R. (1990), Structure and scale in the Roman economy. Cambridge.

Etienne, R. (1957), "Démographie et epigraphie”, in Atti del $3{ }^{\circ}$ Congreso Internazionale di epigrafia greca e latina. Roma, 418-425.

Etienne, R., Fabre, G., Lévêque, P. \& Lévêque, M. (1976), Fouilles de Conimbriga II, Epigraphie et sculpture. Paris.

Frier, B. W. (1992), “Statistics and Roman society”. Journal of Roman Archaeology 5: 286-290.

Frier, B. W. (2000), "Demography". In Cambridge Ancient History, vol. XI, The High Empire AD 70-192. Cambridge, 788-816.

Girri, G. (1956), La taberna nel quadro urbanistico e sociale di Ostia. Roma.

Gonçalves, A. (1903), "Excavações nas ruínas de Conimbriga (Condeixa-a-Velha). Portugalia 1: 359-365.

Hin, S. (2007), "Counting Romans". Princeton/Stanford working papers in Classics (www.princeton.edu/pswpc, cons. 2-11-2009)

Hopkins, M. K. (1965), “The age of Roman girls at marriage”. Population Studies 18, 309-327. 
Hopkins, K. (1967), "On the probable age structure of the Roman population". Population Studies 20: 245-264.

Kolb, C. C. (1985), "Demographic estimates in Archaeology: contributions from etnoarchaeology on Mesoamerican Peasants". Current Anthropology 26-5: 581-599.

Mantas, V. G., (2013), População e mobilidade nas cidades romanas de Portugal, in I Congresso Histórico Internacional. As cidades na história: população. Guimarães, vol. 2, 97-128

Millett, M., (1990), The Romanization of Britain: an essay in archaeological interpretation. Cambridge.

Moretti, L. (1959), “Statistica demográfica ed epigráfica: durata media della vita in Roma imperiale”. Epigraphica 21: 60-78.

Packer, J. E. (1967), "Housing and population in Imperial Ostia and Rome". Journal of Roman Studies 57: 80-95.

Reis, M. P. (2003), Rede de saneamento de Condeixa-a-Velha. Acompanhamento arqueológico. Conimbriga.

Reis, M. P. \& Correia, V. H. (2006), "Jardins de Conimbriga: arquitectura e gestão hidráulica”, in J. P. Morel, J. J. Tresseras e J. C. Matamala, The Archaeology of Crop Fields and Gardens. Ravello, 293-312.

Saquete Chamizo, J. C. (1997), Las elites sociales de Augusta Emerita. Merida.

Scheidel, W. (2001), "Roman age structure: evidence and models". Journal of Roman Studies 91: 1-26.

Scheidel, W. (2004), "Human mobility in Roman Italy, 1: the free population". Journal of Roman Studies 94: 1-26.

Scheidel, W. (2005a), "Human mobility in Roman Italy, 2: the slave population". Journal of Roman Studies 95: 64-79.

Scheidel, W., (2005b), "The comparative economics of slavery in the Greco-Roman world". Princeton/Stanford working papers in Classics (www.princeton.edu/pswpc, cons. 2-11-2009)

Scheidel, W. (2007a), “The Roman slave supply”. Princeton/Stanford working papers in Classics (www.princeton.edu/pswpc, cons. 2-11-2009)

Scheidel, W. (2007b), "Epigraphy and demography: birth, marriage, family and death". Princeton/Stanford working papers in Classics (www.princeton.edu/ pswpc, cons. 2-11-2009)

Scheidel, W. (2007c), "Roman population size: the logic of the debate". Princeton/Stanford working papers in Classics (www.princeton.edu/pswpc, cons. 2-11-2009)

Storey, G. R. (1997), “The population of ancient Rome”. Antiquity 71 : 966-978. 
Calculating the population of a Roman provincial town (Conimbriga, prov. Lusitania, Portugal)

Veyne, P. (2002), “La 'plébe moyenne’ sous le Haut-Empire romain”. Annales, Histoire Sciences Sociales 55-6 : 1169-1199.

Wallace-Hadrill, A. (2008), Rome's cultural revolution. Cambridge. 